ISSN:

Print - 2277-078X

Online - $2315-747 \mathrm{X}$

(c) UNAAB 2017

\title{
GENDER ANALYSIS OF ASSET INEQUALITIES WITHIN RURAL HOUSEHOLDS IN OGUN STATE, NIGERIA.
}

\author{
E. O. OYEDEPO
}

Department of Agricultural Economics and Farm Management

Federal University of Agriculture, Abeokuta, Nigeria.

Corresponding author : lolaoyedepo1@gmail.com Tel+2348038648941

\begin{abstract}
This article examines the evidence available on the distribution of assets by gender in rural households in Ogun State, Nigeria. One of the contributions of feminist economics has been to demonstrate that household and individual welfare are not necessarily the same. Relatively very little work has been done to show gender disparity in ownership of assets in rural Nigeria though gender asset distribution have been found to impact household decisions, women's wellbeing and poverty alleviation. Primary data was collected from a total of 260 households selected through a multistage sampling procedure. The data were analyzed using descriptive statistics. The study finds that an average rural household in the sample was made up of six persons and households were predominantly headed by males (88\%). The mean worth of households' physical assets was 1,218,308.20, about 15\% of which was owned by women. Based on these findings the study recommends that the economic situation of women should be enhanced by promoting their access to productive assets through indigenous savings, credit associations and micro financing. This will enable our society attain the sustainable development goals of gender equality and maternal wellbeing.
\end{abstract}

Keywords: Gender, assets, asset gap, wealth, rural households.

\section{INTRODUCTION}

Agriculture plays a crucial role in the development of the Nigerian economy and rural populations are seen as potential drivers of economic growth. Women represent a crucial resource in agriculture through their roles as farmers, labourers and traders yet they face constraints that reduce productivity and retard progress on broader economic and social development goals (FAO, 2011).

Due to the growing recognition of women's role in agricultural production, there has also been a need to focus on the particular constraint they face in food produc- tion. According to Doss \& al., (2012), one important constraint among many others include that women have lower rates of land and other asset ownership. Recent studies in some developing countries reveal that there are gender differences in ownership of resources within the household and actual levels of wealth or assets are important measures of economic well being. In reality, analyses of income only capture the current state of inequality while wealth has the potential for examining accumulated and historically structured inequality (O liver $\& \mathrm{al}$, 1993; Doss \& al., 2012). Women and men not only may have significantly different access to wealth but also may use their wealth 
and the income it generates for different purposes. This may have consequences for household wellbeing and for the larger society.

It is increasingly recognized that ownership of, access to and control over productive assets are important determinants of the well-being of individuals and households. Assets generate income and facilitate access to capital and credit. They strengthen households' ability to cope with and respond to shocks by enhancing their ability to diversify their income and ease liquidity constraints. A ssets are also a store of wealth which can be sold to generate income (Abena $\&$ al., 2011).

The importance of examining the distribution of wealth by gender can not be over emphasized due to a number of salient facts. According to D eere and D oss, (2006) the first reason the gender distribution of wealth matters is an equity issue. The pattern of wealth ownership by gender world wide suggests that women face greater constraints in earning and keeping wealth. Thus, we need to understand these constraints in order to increase equity.

Gender issues are also central to the attainment of development goals and poverty reduction and they play prominent role in the United Nations Millennium D evelopment Goals (MDGs) and also the current Sustainable Development Goals, which have been commonly accepted as a framework for measuring development progress (Q uisumbing and McClafferty, 2006).

O wing largely to data constraints, however, there has been a tendency for studies on assets and well-being or poverty to use the household as the unit of analysis. Such an approach tends to ignore the importance of intra-household disparities in asset ownership and well-being. Moreover, the dearth of individual-level data on asset ownership makes it extremely difficult to analyze gender disparities in asset ownership, wealth and well-being. As rightly noted by Grown $\& \mathrm{al}$., (2005), this lack of data seriously hampers efforts to track the progress of countries toward the Millennium Development Goal of gender equality and women's empowerment.

Secondly, men and women may use wealth in different ways and this discrepancy can have effects that originate in the household and permeate the larger society. A large body of evidence suggests that the outcomes of household decisions depend on who has more bargaining power within the household.

Since bargaining power is often measured as access to income or ownership of wealth, this suggests that the gender patterns of wealth ownership are important, even within households. Studies have shown that household expenditures differ depending on the assets brought to marriage by each spouse (Q uisumbing and Maluccio, 2003) and that the current asset distribution by gender affects household expenditure patterns on food, health, education and household services (Thomas, 1999; Katz and Chamorro, 2003; D oss, 2006).

Women's assets ownership may affect the anthropometric status of children (D uflo, 2000), the incidence of prenatal care (Beegle $\notin$ al. 2001) and reduce domestic violence (Panda and Agrawal, 2005; Friedemann Sanchez, 2006).

Recent evidence also suggests that assets in 
GENDER ANALYSIS OF ASSET INEQUALITIES WITHIN...

the hands of women empower them, it significantly enhances their decision-making capabilities (D eere and Unidos, 2010; Agarwal 1998), improves well-being at an individual, household and community level and has a greater impact on the health and welfare of children ( Hallman, 2000; Katz and Chamorro 2003). In Ghana women's share of assets has been found to have an impact on some categories of household expenditure (D oss, 2006).

A third reason the gender distribution of wealth may be important is the relationship between assets and poverty. Among the poor, wealth may be very limited but the assets that represent wealth in the form of land, housing, small businesses, or even consumer durables may have an important impact on well being. Incorporating gender into studies of wealth and poverty could also help determine the ways gender intensifies or mitigates financial vulnerability during times of economic stress when assets can provide a degree of security.

A consideration of the gender dimensions of asset ownership would also open doors to an examination of political and economic vulnerability and equity as it is manifested along gender lines, such analyses are important because assets are related to wellbeing and empowerment (D oss, 2006).

This study was conducted to empirically make comparisons in asset ownership between men and women and to show the extent of the differences by gender within the rural household.

\section{Concepts and Method of Analysis}

Ownership may be conceptualised in four different ways. The first is based on perception, which was determined by asking re- spondents who the owner of the asset is. Second, ownership may be based on legal claims established by having one's name on a document.

The third concept of ownership is based on marital laws. Lastly, ownership may be defined based on control over the assets (Abena $\notin \mathrm{al}$, 2011). This study investigated gender gaps that emerge from perception definitions of ownership only while excluding ownership based on legal claims, marital laws and control due to lack of sufficient data to capture these variables in the rural areas.

Two sets of measures have been developed to capture gender differences in asset ownership. The first is the gender asset gap and the second is the gender wealth gap. (Doss \& al.,2012) and Abena \& al.,(2011). The gender asset gap can be measured based on the incidence of asset ownership by sex of owner. This measure is calculated for each category of asset.

The gender wealth gap, on the other hand, is measured by calculating the share of the gross value of assets owned by both men and women in the rural household (Doss $\&$ al., 2012). The gross value of the assets is calculated using the market price or sale value of the assets. Our findings are based on an analysis of both gender asset and wealth gaps.

\section{METHODOLOGY}

The study was carried out in Ogun State. Ogun State is one of the south western states in Nigeria. It is bounded in the south by Lagos State and bounded in the north by Oyo Sate. The study was based on primary data collected from a cross section of 260 rural households drawn by multistage ran- 
dom sampling technique from the study area.

The primary data were sourced through personal interviews with the aid of a questionnaire. Rural households in the four OGADEP zones of Ogun State were the target population. Each zone is made up of a number of blocks. The blocks are further delineated into cells and the cells into subcells and finally subcells are made up of villages. The Ilaro and Ikenne zones are divided into 4 blocks each and the Abeokuta and ijebu ode zones are made up of 6 blocks each.

The study sampled $50 \%$ of the blocks from each zone. This gives a total of 10 blocks. Thereafter, 2 or 3 cells per block (depending on the number of cells in each block) were sampled randomly to give 26 cells in all. Then 1 sub cell per cell was randomly picked to make up 26 sub cells and then one village per sub cell was randomly selected to make up 26 villages. Finally 10 households per village were selected to make a sample size of 260 households in all.

Descriptive statistics such as frequency counts and percentages were used to describe information for the socio economic characteristics of the rural households and to assess and compare the levels of physical and human assets owned by the male household heads and their spouses in the study area.

In this study, the gender asset and gender wealth gap were investigated among male headed households with at least one wife. In cases where the household is polygamous information was obtained from the first wife in order of marriage and where she is dead the next wife in the same order. Male headed households formed the majority of the total population sampled.

\section{RESULTS \\ General characteristics of the rural households in $\mathbf{O}$ gun State.}

The general characteristics of the sampled rural households in the study are presented in Table 1, showing the household type, household size, type of housing unit, and sex of the household head. All these variables are indicators of the present socio economic condition of the rural households. The unit of analysis in this study is the rural household.

\section{H ousehold type, size and housing unit}

About 70 percent of the rural households were from the monogamous family whereby the household head had only one wife. The remaining 30 percent is made up of households where the husband had two, three or more wives. Polygamous families generally have larger household sizes. This information supports the result obtained for the household size in the sampled population whereby the majority of the households (about 55 percent) have household size between 2-5 persons. The average household size from the sampled population is 6 persons, and it compares favourably with the average household size of 6.0 for households in $\mathrm{O}$ gun State according to the National Bureau of Statistics NBS, (2005). Male headed households were 88.07 percent while female headed households made up the remaining 11.93 percent. Over 90 percent of the sampled rural households live in room by room ("face-to-face") buildings while only 7 percent occupy flats. The "face to face" housing unit is the most common among the rural households and it is typical of most rural settlements in south-western Nigeria. 
Table 1: General characteristics of the rural households in 0 gun state

\begin{tabular}{llll}
\hline & Frequency & Percentage & Mean \\
\hline $\begin{array}{l}\text { 1. Type of household } \\
\text { Monogamous family }\end{array}$ & 178 & 68.5 & \\
$\quad$ Polygamous family & 82 & 31.5 & \\
$\quad$ Total & 260 & 100 & \\
2. Household size & & & \\
$\quad 2-5$ & 142 & 54.62 & 6 \\
$\quad 6-9$ & 88 & 33.85 & \\
$\quad 10-13$ & 27 & 10.38 & \\
$\quad 34-17$ & 3 & 1.15 & \\
$\quad$ Total & 260 & 100 & \\
3. Type of housing unit & & & \\
Single room & 238 & 91.54 & \\
$\quad$ Flat & 228.46 & & \\
4. Sex of household head & & & \\
Male & 229 & 88.07 & \\
$\quad$ Female & 31 & 11.93 & \\
Total & 260 & 100 & \\
\hline
\end{tabular}

Source: Computed from field survey, 2012.

Gender Asset Gap within the rural households.

Table 2 shows the individual level ownership of physical assets among male household heads and their spouses. Precisely 32 percent of the men had land in the rural area while only 13 percent of the women indicated ownership of land in the rural area. Similarly, 35 percent of the men owned farmland for agricultural purposes while only 6 percent of the women owned farmland. Some of the women indicated that they were allowed to have access to some farm land for agricultural purposes but could not lay claims. This result is in line with what was obtained by Enwelu \& al., (2014) in their study about the access of women farmers to land for agricultural purposes in Anambra State, Nigeria. They discovered that women's right to the husband's land is secure as long as the marriage lasts and unmarried women are not allowed to inherit landed property in patriarchal societies like we have in Nigeria. This view was buttressed by British Council of Nigeria (2012) which reported that though women are involved in subsistence agriculture and off farm activities, men are five times more likely than women to own land. However, a relatively greater percentage of the women possessed assets such as grinding mill (30 percent) and freezer (20 percent). These assets were used by the women to generate income for the family. 
Table 2: Individual level 0wnership of Physical assets in the rural households.

\begin{tabular}{|c|c|c|c|c|}
\hline \multicolumn{3}{|c|}{ Husband } & \multicolumn{2}{|c|}{ Wife } \\
\hline Asset type & Frequency & Percentage & Frequency & Percentage \\
\hline Land (rural) & 74 & 32.31 & 31 & 13.54 \\
\hline Land (urban) & 5 & 2.18 & 3 & 1.31 \\
\hline Farmland & 80 & 34.93 & 6 & 2.62 \\
\hline House (rural) & 60 & 26.20 & 16 & 6.99 \\
\hline House (urban) & 29 & 12.66 & 5 & 2.18 \\
\hline G rinding mill & 10 & 4.37 & 68 & 29.69 \\
\hline Freezer & 27 & 11.79 & 45 & 19.65 \\
\hline Motorcycle & 74 & 32.31 & 0 & 0.00 \\
\hline Vehicle & 46 & 20.09 & 2 & 0.87 \\
\hline Television & 152 & 66.38 & 22 & 9.60 \\
\hline Video & 132 & 57.34 & 19 & 8.30 \\
\hline Radio & 137 & 59.83 & 36 & 15.72 \\
\hline Tape recorder & 65 & 28.38 & 7 & 3.06 \\
\hline Stove & 5 & 2.18 & 192 & 83.84 \\
\hline Total household & \multicolumn{4}{|l|}{229} \\
\hline \multicolumn{5}{|c|}{ Source; Computed from field survey } \\
\hline \multicolumn{5}{|c|}{$\begin{array}{l}\text { Gender Wealth Gap within the nural percent and } 100 \text { percent respectively. On the } \\
\text { households. } \\
\text { other hand, their wives have a smaller per- } \\
\text { centage share of these assets ranging be- } \\
\text { Table } 3 \text { shows the distribution of asset in tween } 8 \text { and } 30 \text { percent. This is because } \\
\text { terms of wealth within the rural households. women are generally asset poor in the rural } \\
\text { The husbands have a larger percentage areas and they personally own these items } \\
\text { share of assets such as houses in the rural only when they can afford them. On a gen- } \\
\text { area, landed property in the rural area, farm- } \\
\text { land, vehicles and motorcycles at } 76.50 \text { per- } \\
\text { cent, } 77.91 \text { percent, } 92.00 \text { percent, } 93.68 \text { grinding mill and freezer. }\end{array}$} \\
\hline
\end{tabular}


GENDER ANALYSIS OF ASSET INEQUALITIES WITHIN...

Table 3: Gender Distribution of value of assets within the rural households

\begin{tabular}{|c|c|c|c|c|c|}
\hline $\begin{array}{l}\text { House } \\
\text { (rural) }\end{array}$ & $100,000,000.00$ & $76,500,000.00$ & $23,500,000.00$ & 76.50 & 23.50 \\
\hline $\begin{array}{l}\text { House } \\
\text { (urban) }\end{array}$ & $132,000,000.00$ & $120,000,000.00$ & $12,000,000.00$ & 90.91 & 9.09 \\
\hline $\begin{array}{l}\text { Land } \\
\text { (rural) }\end{array}$ & 25,374,998.00 & $19,770,000.00$ & $5,605,000.00$ & 77.91 & 22.09 \\
\hline $\begin{array}{l}\text { Land } \\
\text { (urban) }\end{array}$ & $3,240,000.00$ & $2,240,000.00$ & $1,000,000.00$ & 69.14 & 30.86 \\
\hline Farmland & $16,640,000.00$ & $15,308,000.00$ & $1,331,200.00$ & 92.00 & 8.00 \\
\hline Vehicle & $28,499,999.00$ & $26,700,000.00$ & $1,800,000.00$ & 93.68 & 6.32 \\
\hline Motorcycle & $5,902,000$ & $5,902,000.00$ & - & 100.00 & - \\
\hline $\begin{array}{l}\text { Grinding } \\
\text { mill }\end{array}$ & $903,000.00$ & $108,360.00$ & $794,640.00$ & 12.00 & 88.00 \\
\hline Freezer & $1,325,000.00$ & $115,000.00$ & $1,210,000.00$ & 8.68 & 91.32 \\
\hline Stove & $208,650.00$ & $10,432.50$ & $198,217.5 S 0$ & 5 & 95.00 \\
\hline Television & $2,648,000.00$ & $2,321500.00$ & $326,500.00$ & 87.67 & 12.33 \\
\hline $\begin{array}{l}\text { Radio } \\
\text { Total value }\end{array}$ & $\begin{array}{l}217,500.00 \\
316760.132 .50\end{array}$ & $\begin{array}{l}180,200.00 \\
269155.492 .50\end{array}$ & $\begin{array}{l}37,300.00 \\
47604640\end{array}$ & 82.85 & 17.15 \\
\hline $\begin{array}{l}\text { average } \\
\text { value }\end{array}$ & & $1,035,213.00$ & & 84.97 & 15. \\
\hline
\end{tabular}

\section{Gender differences in human capital} endowment.

\section{Education}

According to FAO, (2011) education plays a major role not only for individual's opportunities in society, but also for the productive capacity and wellbeing of a household. Almost universally, studies that analyze income, agricultural production, and other measures of welfare have established that education, which is the human capital available in the household (usually measured as the education of the head of household, or the average education of working age adults) is strongly correlated with these welfare measures. Cross-country studies have come to show that gender inequality in educational levels is important (World Bank, 1999) for a wide range of outcomes, including malnutrition, health, employment opportunities, and technology adoption, all of which ultimately affect household incomes and economic growth at the national level. 
E. O.OYEDEPO

Table 4: Human Capital Endowment Within the Rural Household.

\begin{tabular}{|l|l|l|l|l|}
\hline $\begin{array}{l}\text { Level of Edu- } \\
\text { cation }\end{array}$ & $\begin{array}{l}\text { Frequency } \\
(\text { Men) }\end{array}$ & $\begin{array}{l}\text { Percentage } \\
(\text { Men })\end{array}$ & $\begin{array}{l}\text { Frequency } \\
\text { (Women) }\end{array}$ & $\begin{array}{l}\text { Percentage } \\
\text { (Women) }\end{array}$ \\
\hline No Education & 55 & 24.20 & 82 & 35.81 \\
\hline Primary 6 & 91 & 39.73 & 71 & 31.00 \\
\hline $\begin{array}{l}\text { Junior Second- } \\
\text { ary 3 }\end{array}$ & 27 & 11.79 & 36 & 15.72 \\
\hline SSCE & 37 & 16.16 & 32 & 13.97 \\
\hline GRAD E II & 2 & 0.87 & 1 & 0.44 \\
\hline NCE/ ND & 5 & 2.00 & 0 & 0.00 \\
\hline HND & 4 & 1.76 & 2 & 0.87 \\
\hline B.Sc & 8 & 3.49 & 5 & 2.18 \\
\hline Total & 229 & 100.00 & 229 & 100.00 \\
\hline
\end{tabular}

Source; Computed from field survey, 2012.

Table 4 reveals that 36 percent of the women had no formal education. Those who had primary school education were 31 percent of the total number of wives sampled. Very few of the women had tertiary education though 64 percent of them had completed at least primary school education. The male household educated than their wives as 75.8 percent of them had completed at least primary school education, about 5 percent had tertiary education while 24 percent had no form of formal education. In terms of age, the result on Table 5 reveals that majority of the women were still economically acheads in the study area were relatively more tive and their average age was 40 years.

Table 5: Age of male household heads and their wives.

\begin{tabular}{|l|l|l|l|l|l|l|}
\hline $\begin{array}{l}\text { Age } \\
\text { (Yrs) }\end{array}$ & $\begin{array}{l}\text { Frequency } \\
\text { (Men) }\end{array}$ & $\begin{array}{l}\text { Percentage } \\
\text { (Men) }\end{array}$ & $\begin{array}{l}\text { Mean } \\
\text { Age } \\
\text { (Men) }\end{array}$ & $\begin{array}{l}\text { Frequency } \\
\text { (Women) }\end{array}$ & $\begin{array}{l}\text { Percentage } \\
\text { (Women) }\end{array}$ & $\begin{array}{l}\text { Mean Age } \\
\text { (Women) }\end{array}$ \\
\hline $\begin{array}{l}\text { Below } \\
30\end{array}$ & 9 & 3.93 & & 43 & 18.77 & \\
\hline $31-40$ & 59 & 25.76 & & 88 & 38.42 & \\
\hline $41-50$ & 92 & 40.17 & 49 & 38 & 16.59 & 40 \\
\hline $51-60$ & 44 & 19.21 & & 50 & 21.83 & \\
\hline $\begin{array}{l}\text { Above } \\
60\end{array}$ & 26 & 11.35 & & 10 & 4.37 & \\
\hline Total & 229 & 100.00 & & 100.00 & & \\
\hline
\end{tabular}

Source; Computed from field survey, 2012.

J. Hum. Soc. Sci. Crtv. Arts 2017, 12: 28-37 


\section{CONCLUSION}

This study confirms the prevalence of gender disparities in asset ownership and control in the study area and further suggest that asset ownership is crucial for the empowerment of women. The men had more physical assets, were wealthier and better educated than their female counterparts. These findings strongly point to the need for policy measures that will address the underlying causes of the disparities, a task that requires the involvement of all stakeholders. The study additionally confirms the importance of collecting nationally representative individual-level data on asset ownership. The collection of individual-level data on asset ownership will facilitate the tracking of progress towards the attainment of the Sustainable D evelopment Goals.

\section{REFERENCES}

Abena, D.0, Baah - Boateng, W, and Boakye - Yiadom, L. 2011.' Measuring the Gender Asset Gap in Ghana'. Published for the Department of Economics; University of G hana, Legon by Woeli Publishing Services, Ghana.

Agarwal, B. 1998 "Widows vs. Daughters or Widows as Daughters? Property, Land and Economic Security in Rural India in M. Chen (ed.) Widons in India: Social Negeet and Public Adion Sage Publications, New Delhi.

Beegle, K., Frankenberg, E. and Thomas, D., 2001. Bargaining Power within couples and use of prenatal and delivery care in Indonesia. Studies in Family Planning 32(2), 130 $-146$.

British Council of Nigeria. 2012. G ender J. Hum. Soc. Sci. Crtv. Arts 2017, 12: 28-37 in Nigeria report: Improving the lives of girls and women in Nigeria. Issues, Policies and action $2^{\text {nd }}$ edition.

Deere, C. D. and Doss, C. 2006. The Gender Asset Gap'. What do we know and why does it matter? Feminist Economics 12 (1\&2): 1-50.

Deere, C. D. and Unidos, E. 2010. Poverty, Headship and G ender Inequality in Asset Ownership in Latin America. Research working Paper No. 296. Center for G ender in Global Context, Michigan State University.

Doss, C. 2006. "The Effects of Intrahousehold Property Ownership in ExpenditurePatternsi in Ghana" Jamal of African Economes, Vol. 15, No. 1, pp. 149-180.

Doss, C., Deere, C.D. Abena, D. O. and Suchira J.Y. 2012 The Rural G ender Asset and Wealth $\mathrm{G}$ aps. Evidence from Ghana, Ecuador, Uganda and Karnataka, India. Indian Institute of Management, Bangalore, India.

Duflo, E. 2000. "Grandmothers and Granddaughters: Old-Age Pension and Intra household Allocation in South Africa.", Department of Economics, Massachusetts Institute of Technology.

Enwelu, I.A., Morah, U.L. Dimelu, M.U. Ezeano, C.I. 2014. Women Farmers Access and Use of Land for Agriculture in selected communities in Anambra State, Nigera. Meet iteranean Jaumal of Soial Saienes 5(26): 37 43. MCSER Publishing, Rome, Italy.

FAO, 2011 Gender D ifferences in Assets. Research Working Paper No. 11-12, Agricultural Economics D ivision, Food and Agriculture O rganization of the United Nations. 
www.fao.org/ economic/ esa.

Freidemann-Sanchez, G. 2006 "Assets in Intra household Bargaining among Women Workers in Colombia's Cut-Flower Industry", Feminist Econmics Vol. 12, Nos. 1 \& 2, pp. 247-69.

Hallman, K. (2000). Mother-Father Resource Control, Marriage Payments and Girl -Boy Health in Rural Bangladesh. Food Consumption and Nutrition Division Discussion Paper 93.Washington, D C. International Food Policy Research Institute.

Katz, E. And J.S. Chamorro 2003. "Gender, Land Rights and the Hausdhdd Econo myin Rural Nicaragua and Honduras", A paper presented at the annual Conference of the Latin American and Caribbean Economics Association, Puebla, Mexico.

Oliver, M., Shapiro, T . and Press, J. 1993

'Them that's got shall get': inheritance and achievement in wealth accumulation', Re searchin Pditics and Socity, 5, 69-95.

Panda, P. and Agarwal, B. 2005. Marital Violence, Human D evelopment and Wom- en's property status in India,' Wodd Dedep ment33 (5) ; 823-850.

Quisumbing, A. R; and Maluccio, J. A. 2003. "Resources at Marriage and Intra household Allocation: Evidence from Bangladesh, Ethiopia, Indonesia, and South Africa," Oxford Bullein of Economics and Statistics, 65(3): 283-327.

Quisumbing, A. R; and McClafferty, B. 2006. Food Security in Practice. Using G ender

Research in D evelopment. International Food Policy Research Institute, Washington DC.

Thomas, D. 1999. 'Intrahousehold Resource Allocation: An Inferential Approach'. Jaumal of Human Resaurces 25(4): 635-64.

World Bank, 1999. Gender, G rowth, and Poverty Reduction. Africa Region Findings, Research Paper No129, Washington, D.C. World Bank.

(Manusaipt reeiveet 4thJuly, 2017; accepted 21st March, 2018). 